\title{
Chronic Intermittent Hypoxia Protects the Rat Heart Against Ischemic/Reperfusion Injury by Modulating Apoptosis: A Possible Role for Endogenous Nitric Oxide
}

\author{
Samah El-Attar \\ The Physiology Department, Faculty of Medicine, Cairo University
}

\begin{abstract}
Background: Intermittent hypoxia has been shown to provide myocardial protection against ischemia/reperfusion injury. Cardiac myocyte loss through apoptosis has been reported in ischemia/reperfusion injury. The role of nitric oxide (NO) in modulating apoptosis in rats exposed to chronic intermittent hypoxia is controversial. The aim of the present work is to investigate the possible role of nitric oxide synthase inhibition on modulation of apoptosis in ischemic- reperfused isolated hearts of rats exposed to chronic intermittent hypoxia. Methods: Adult male albino rats were used and exposed to normaxic or hypoxic conditions as follows: Group I: Normoxic conditions (normoxia group), Group II : Chronic intermittent hypoxia (CIH group) (10\% O2 and 90\% N2) for 8 hours daily, then to normal environmental air for the rest of the day, 5 days/ week for 4 weeks, Group III: Normoxic conditions and treated with L-NAME (10 mg/kg B.W. via intra-gastric route) (L-NAME group), Group IV: Chronic intermittent hypoxia and treated with L-NAME (CIH + L-NAME group) They had daily L-NAME(10 mg/kg B.W. via intra-gastric route) and exposed to the chronic intermittent hypoxia in the same way and duration as rats of group II. Isolated perfused hearts were subjected to 30 minutes of global ischemia followed by 30 minutes reperfusion. Left ventricular developed pressure (LVDP), contractility (dp/dt), and heart rate (HR) were recorded continuously. Expression of Bcl-2 in the myocardium was detected. Results: The parameters of functional recovery were improved in $\mathrm{CIH}$ group with significant increase in Bcl-2 expression as compared to normoxia group. Treatment with L-NAME led to attenuation of improved postischemic recovery of the ventricular function provided by chronic intermittent hypoxia with significant reduction in Bcl-2 expression compared with CIH group. Conclusion: adaptation to chronic intermittent hypoxia increases cardiac tolerance to ischemia/reperfusion. This protective effect was associated with increased expression of the antiapoptotic protein $\mathrm{Bcl}-2$, that limits the apoptotic cell death in the myocardium following the ischemic/reperfusion insult. L-NAME attenuated both the improved recovery of cardiac function and the expression of antiapoptotic protein Bcl-2 induced by $\mathrm{CIH}$.
\end{abstract}

\section{INTRODUCTION}

Hypoxic states of the heart belong to the most frequent and dangerous diseases of modern time.
They result from disturbed oxygen supply to cardiac cells, which is insufficient to meet their metabolic demands. $^{(1)}$ 
Experimental and clinical studies have focused on the question of how cardiac tolerance to oxygen deprivation might be increased. (2) Adaptation to chronic hypoxia and various forms of preconditioning represent well defined and reproducible means to improve cardiac ischemic tolerance. ${ }^{(3)}$ Chronic hypoxia, simulated in a barochamber, results in enhanced cardiac resistance in rats, but the precise mechanisms of this cardiac protection by adaptation to chronic hypoxia are still unclear. ${ }^{(4)}$

Apoptosis has been shown to contribute to myocardial reperfusion injury. Recent studies have demonstrated that myocardial ischemia and reperfusion result in apoptotic cell death, in addition to tissue necrosis. ${ }^{(5 \& 6)}$ However apoptosis does not become apparent until hearts are reperfused following an ischemic insult. ${ }^{(7)}$ Webster et al., ${ }^{\left({ }^{8}\right)}$ have demonstrated that in an in vivo model, both reperfusion, and hypoxia are strong stimuli for the induction of apoptosis. In fact, an increased rate of apoptosis has been observed in cerebral and cardiac reperfusion in animal models, suggesting that the deleterious effect during reperfusion is, at least in part, due to apoptosis. ${ }^{(9)}$

Although hypoxia may increase the incidence of apoptosis in cultured cardiomyocytes, the influence of chronic oxygen tension changes on apoptosis in cardiac cells in vivo is less clear. During hypoxia, there is cessation of mitochondrial oxidative phosphorylation, which normally fulfills the high metabolic needs of cardiomyocytes, and ATP is produced by much less efficient anaerobic glycolysis. ${ }^{(10)}$ Immediate resumption of oxidative phosphorylation by reoxygenation, therefore, is critical for restoring adequate ATP production and cell survival. However, an abrupt rise in reactive oxygen species in mitochondria during reoxygenation has been associated with a deleterious effect on cardiomyocytes. ${ }^{(11)}$

Because the amount of myocardial damage in patients with ischemic heart disease is the most important determinant of morbidity and mortality, limiting the loss of cardiomyocytes during oxidative stress will have important therapeutic implications. ${ }^{(10)}$ It has been suggested that, in reducing the apoptotic component within the ischemic area at risk, Bcl-2 (B-cell CLL/lymphoma 2) over-expression could lead to a ventricular function improvement. ${ }^{(12)}$

It is a well accepted concept that intracellular proteins of Bcl-2 family can be part of the apoptotic signaling cascade in which Bcl-2 exhibits antiapoptotic actions. ${ }^{(13)} \mathrm{Bcl}-2$, a mammalian homologue of the antiapoptotic gene ced-9 in C elegans, is localized mainly to the mitochondrial membrane ${ }^{(14)}$ and is a prototypical member of the Bcl-2 family of proteins that modulates apoptotic responses in various cell types. ${ }^{(15 \& 16)} \mathrm{Bcl}-2$ mRNA and proteins are expressed in developing and adult heart, ${ }^{(17)}$ and the protein is upregulated after coronary occlusions. ${ }^{(18)}$ However, the effects of Bcl-2 in heart have not been well characterized, and little is known about the effects of Bcl-2 in heart. ${ }^{(8)}$

Treatment with various NOdonating compounds is highly effective in the setting of myocardial $\mathrm{I} / \mathrm{R}$ (MI/R) injury. NO has also 
recently emerged as a crucial modulator of myocardial preconditioning, and NO is thought to mediate cardioprotection during the preconditioning process. ${ }^{(19)}$ The role of nitric oxide (NO) in $\mathrm{I} / \mathrm{R}$ injury and cardioprotection is complex and not fully understood. This molecule can increase cardiac ischemic tolerance by a number of cyclic GMP-dependent and independent mechanisms. ${ }^{(20)}$

Thus, a primary objective of the present study was to investigate the possible role of nitric oxide synthase inhibition on modulation of apoptosis in ischemic- reperfused isolated hearts of rats exposed to chronic intermittent hypoxia.

\section{Materials and Methods:}

Forty adult male albino rats weighing 200-250 gram were used in this study. They were divided into four groups;

Group I: Normoxia group, 10 rats were used as control rats and were exposed to normal atmospheric air.

Group II: Chronic intermittent hypoxia group, $(\mathrm{CIH}), 10$ rats were used in this group and they were exposed to chronic intermittent hypoxia. The rats were placed in closed box and exposed to hypoxia $(10 \% \mathrm{O} 2$ and $90 \% \mathrm{~N} 2)$ for 8 hours daily, then to normal environmental air for the rest of the day, 5 days/ week for 4 weeks ${ }^{(21)}$

Group III: Normoxia group treated with L-NAME (L-NAME group), 10 rats were used in this group. They had daily L-NAME in a dose of $(10 \mathrm{mg} / \mathrm{kg}$ B.W. via intra-gastric route) ${ }^{(22)}$ and were exposed to normal atmospheric air. Group IV: (CIH + L-NAME group) 10 rats were used in this group. They had daily L-NAME in a dose of
(10 $\mathrm{mg} / \mathrm{kg}$ B.W. via intra-gastric route) $)^{(22)}$ and exposed to the chronic intermittent hypoxia in the same way and duration as rats of group II.

All rats had free access to water and fed on normal laboratory chow. They were exposed to 12-12 lightdark cycles placed in boxes at room temperature $23 \mathrm{C}$.

Langendorff Preparation:

Isolated heart perfusion was performed as described. ${ }^{(4)}$ Sodium pentobarbital (45 $\mathrm{mg} / \mathrm{kg})$ was administered by intraperitoneal injection. The heart was excised, and the ascending aorta was cannulated and perfused at a constant pressure of $100 \mathrm{~cm} \mathrm{H}_{2} \mathrm{O}$ with Krebs-Henseleit buffer (in $\mathrm{mmol} / \mathrm{L}$, glucose $11, \mathrm{NaCl}$ $118, \mathrm{NaHCO}_{3} 25, \mathrm{CaCl}_{2}$ 1.2, $\mathrm{KCl} 4.7$, $\mathrm{KH}_{2} \mathrm{PO}_{4}$ 1.2, and $\mathrm{MgSO}_{4} 1.2$ ), which was maintained at $37^{\circ} \mathrm{C}$ and bubbled continuously with a mixture of $95 \%$ $\mathrm{O}_{2}$ and $5 \% \mathrm{CO}_{2}$. A fluid-filled latex balloon was inserted into the left ventricle and inflated to an initial enddiastolic pressure of 4 to $8 \mathrm{~mm} \mathrm{Hg}$. Left ventricular developed pressure (LVDP), contractility (dp/dt), and heart rate (HR) were recorded continuously. Left ventricular developed pressure (LVDP) was calculated as the difference between the systolic and end-diastolic pressures.

Experimental protocol:

After a period of stabilization, baseline values of left ventricular developed pressure (LVDP), contractility $(\mathrm{dp} / \mathrm{dt})$ and heart rate (HR) were recorded. Then, an additional 5 min perfusion was carried out and values were again recorded. All hearts were then exposed to 30 min of sustained global ischemia 
followed by reperfusion for $30 \mathrm{~min}$. The values of LVDP, contractility and HR were measured at 10 min intervals during the reperfusion period, and were expressed as percentage of baseline value.

\section{Detection of bcl2 gene expression} by RT-PCR:

Gene expression of Bcl-2 was detected by reverse transcriptase polymerase chain reaction (RT-PCR). About $30 \mathrm{mg}$ of heart tissue was homogenized then centrifuged at $14,000 \mathrm{rpm}$ for $10 \mathrm{~min}$. The supernatant was examined for detection of Bcl-2 expression.

\section{RNA extraction:}

RNA was extracted from tissue homogenate by acid guanidium thiocyanate, phenol chloroform. The RNA was reverse transcribed into cDNA by adding the following single strength RNA, PCR buffer, $5 \mathrm{mM}$ $\mathrm{mgcl}_{2}, \quad 10 \mathrm{mM} \quad \mathrm{dNTP} \quad$ (deoxy nucleotide triphosphate) mixture, $0.25 \mathrm{ul}$ reverse transcriptase and $2.5 \mathrm{mMol}$ random primer. The mixture was incubated at $42^{\circ} \mathrm{C}$ for 25 min then $5 \mathrm{~min}$ at $95^{\circ} \mathrm{C}$ then chilled on ice. The PCR was performed in a total of volume of $80 \mathrm{ml}$ using specific primer of Bcl-2

5'GGGCTGAAAAGATTGGATCA3' and.

R:5'TCGAACAAATACCAGGAGC3'.
Taq polymerase $(2.5 \mathrm{ul}), \mathrm{mgcl}_{2}$ (4mM), PCR cycling condition was performed for 40 cycles formed of $94^{\circ} \mathrm{C}$ for one minute, $55^{\circ} \mathrm{C}$ for one minute and $72^{\circ} \mathrm{C}$ for two minutes.

About 10ul of PCR product were electrophorised on $1.5 \%$ agarose gel stained with Ethedium Bromide and visualized by UV transilluminator, PCR products were semiquantitated using gel documentation system (BIODOC analyze) supplied by Biometra. $^{(23)}$

\section{Statistics}

Values are measured as mean \pm SD. Comparison of data was performed by using ANOVA test (analysis of variance test). Probability $(P)$ values of $<0.05$ were considered to be significant. ${ }^{\text {(24) }}$ Recovery was expressed as a ratio of post-ischemic value over the pre-ischemic value for LVDP, dp/dt and HR, thus each heart served as its own control.

\section{RESULTS}

Basal functional parameters of the perfused rat hearts (LVDP), $(\mathrm{dp} / \mathrm{dt})$, and heart rate (HR) are summarized in table1. There were no significant differences between the different rat groups. 
Table (1): Left Ventricular developed pressure (LVDP) (mmHg), contractility $(\mathrm{dp} / \mathrm{dt})(\mathrm{cm} / \mathrm{s})$, heart rate (beats/min) in different studied groups before induction of ischemia

\begin{tabular}{|l|l|l|l|l|}
\hline & $\begin{array}{l}\text { Normoxia } \\
\text { group }\end{array}$ & CIH group & $\begin{array}{l}\text { Normoxia+ L- } \\
\text { NAME }\end{array}$ & $\begin{array}{l}\text { CIH+ } \\
\text { L-NAME }\end{array}$ \\
\hline $\begin{array}{l}\text { LVDP }(\mathrm{mmHg}) \\
\text { Mean } \pm \text { S.D. }\end{array}$ & $70.3 \pm 2.8$ & $70.7 \pm 3.0$ & $70.4 \pm 3.6$ & $71.0 \pm 2.6$ \\
\hline $\begin{array}{l}\text { Dp/dt (cm/s) Mean } \pm \\
\text { S.D. }\end{array}$ & $126.4 \pm 2.0$ & $125.5 \pm 2.9$ & $125.1 \pm 3.0$ & $125.3 \pm 2.7$ \\
\hline $\begin{array}{l}\text { HR (beats/min) } \\
\text { Mean } \pm \text { S.D. }\end{array}$ & $119.5 \pm 2.5$ & $120.0 \pm 3.9$ & $119.6 \pm 3.0$ & $120.9 \pm 2.9$ \\
\hline$p$ & & $>0.05$ & $>0.05$ & $>0.05$ \\
\hline
\end{tabular}

Parameters of functional recovery of hearts in the different study groups:

After acquisition of baseline data, hearts were subjected to $30 \mathrm{~min}$ of global ischemia by halting the perfusion pump, followed by $30 \mathrm{~min}$ reperfusion. Upon reperfusion of hearts from rats exposed to normal atmosphere (G1), LVDP values immediately decreased to $71 \%$, the $\mathrm{dp} / \mathrm{dt}$ were reduced to $69.8 \%$ and the heart rate values were reduced to $82.7 \%$ of the basal recorded values (Table 2, Figures 1,2,3).

Table (2) shows that, in hearts exposed to $10 \% \mathrm{O} 2$ for 8 hours daily for 4 weeks (CIH group), LVDP attained approximately $92.2 \%$ of the basal values after reperfusion with significant improved recovery compared to normoxia group(figure 1). $\mathrm{CIH}$ group also showed a better restoration of contractility that was $85.5 \%$ of the basal recorded values and was significantly increased as compared with normoxia group (figure 2). The heart rate was $91.6 \%$ restored after reperfusion with significant higher values as compared with normoxia group (figure 3). Also, it can be seen from figures $1,2,3$ that the recorded values in the L-NAME treated normoxic group were not significantly changed as compared with normoxia group.

To determine whether the increased resistance to myocardial ischemia/reperfusion in hearts subjected to $\mathrm{CIH}$ was mediated by a mechanism involving NO or not, a group of rats were treated with LNAME and exposed to chronic intermittent hypoxia for 4 weeks (CIH+ L-NAME). On reperfusion, LVDP attained $77.6 \%$ of the basal recorded values of this group, with significant reduction compared with $\mathrm{CIH}$ group. Furthermore, the contractility recovered only to $75.2 \%$ of the basal recorded values versus $85.5 \%$ in CIH group. The heart rate was $84.3 \%$ restored at the end of reperfusion period with significant reduction as compared with $\mathrm{CIH}$ group. These values indicates a significant reduction in functional recovery of hearts from $\mathrm{CIH}+\mathrm{L}-$ NAME group compared with values obtained from $\mathrm{CIH}$ group, although, there were a significant better recovery as compared with normoxia group( table 2, figures 1,2,3). 
Table (2): Percent of recovery of left ventricular developed pressure (LVDP), contractility (dp/dt), heart rate (HR) in different studied groups after ischemia/ reperfusion.

\begin{tabular}{|l|l|l|l|l|}
\hline & $\begin{array}{l}\text { Normoxic } \\
\text { group }\end{array}$ & $\begin{array}{l}\text { CIH } \\
\text { group }\end{array}$ & $\begin{array}{l}\text { Normoxia+ } \\
\text { L.NAME }\end{array}$ & $\begin{array}{l}\text { CIH+L- } \\
\text { NAME }\end{array}$ \\
\hline $\begin{array}{l}\text { Percent of recovery of } \\
\text { LVDP(mmHg) } \\
\text { Mean } \pm \text { S.D. }\end{array}$ & $71.0 \pm 2.2^{*}$ & $92.2 \pm 4.4^{\circ}$ & $72.4 \pm 4.5^{*}$ & $77.6 \pm 2.2^{* 0}$ \\
\hline $\begin{array}{l}\text { Percent of recovery of } \\
\text { dp/dt (cm/s) } \\
\text { Mean } \pm \text { S.D. }\end{array}$ & $69.8 \pm 2.1^{*}$ & $85.5 \pm 2.4^{\circ}$ & $68.8 \pm 1.8^{*}$ & $75.2 \pm 1.9^{* 0}$ \\
\hline $\begin{array}{l}\text { Percent of recovery of } \\
\text { HR (beats/min) } \\
\text { Mean } \pm \text { S.D. }\end{array}$ & $82.7 \pm 1.5^{*}$ & $91.6 \pm 4.2^{\circ}$ & $81.3 \pm 3.2^{*}$ & $84.3 \pm 1.7^{* 0}$ \\
\hline
\end{tabular}

${ }^{\circ}$ Significant change compared with normoxic group $(P<0.05)$

* Significant change compared with CIH group $(P<0.05)$.

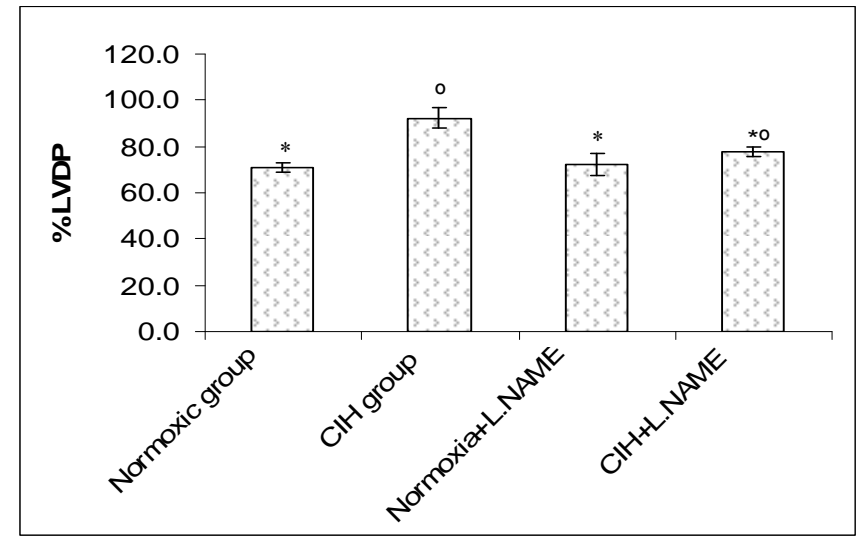

Fig. (1): Percent of recovery of left ventricular developed pressure (LVDP) (mmHg) after ischemia/reperfusion in different studied groups.

${ }^{\circ}$ Significant change compared with normoxic group * Significant change compared with CIH group. 


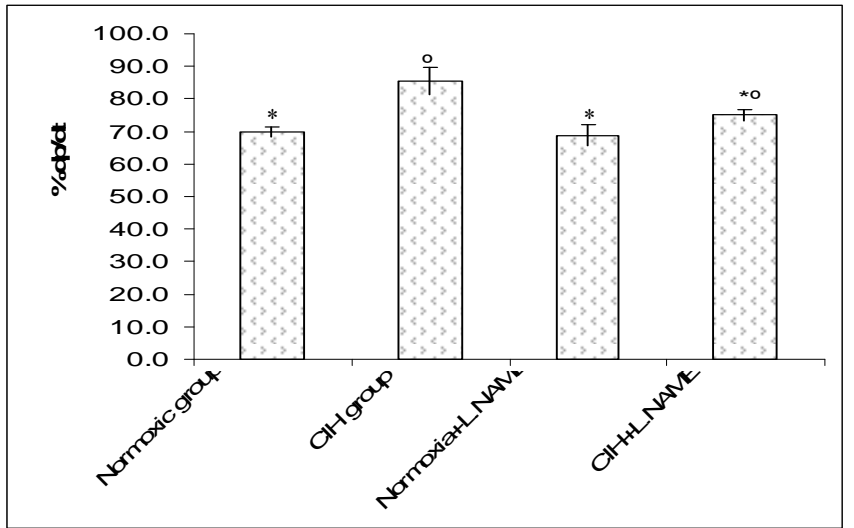

Fig. (2): Percent of recovery of contractility $(\mathrm{dp} / \mathrm{dt})(\mathrm{cm} / \mathrm{s})$ after ischemia/reperfusion in different studied groups.

oSignificant change compared with normoxic group* Significant change compared with CIH group.

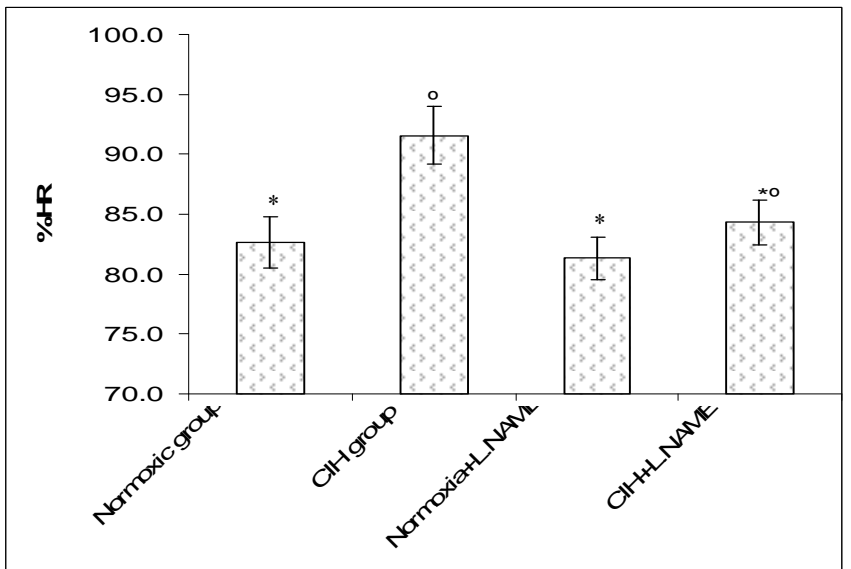

Fig. (3): Percent of recovery of heart rate(beats/min) after ischemia/reperfusion in different studied groups.

${ }^{\circ}$ Significant change compared with normoxic group * Significant change compared with $\mathrm{CIH}$ group.

Bcl-2 expression:

The quantification of $\mathrm{Bcl}-2$ protein expression in protein homogenates from normoxic and hypoxic groups revealed that, Bcl-2 expression level was significantly up regulated in ischemically adapted hearts in the $\mathrm{CIH}$ group with mean value of $5.1 \pm 0.2 \mathrm{ng} / \mathrm{mg}$ of cardiac tissue compared with normoxia group $(1.9 \pm 0.2 \mathrm{ng} / \mathrm{mg}$ of cardiac tissue). We next determined the extent 
to which L-NAME affect the expression of Bcl-2 gene. It was found that in rats treated with L-NAME during the exposure to $\mathrm{CIH}(\mathrm{CIH}+\mathrm{L}-$ NAME group), Bcl-2 gene expression was $2.9 \pm 0.2 \mathrm{ng} / \mathrm{mg}$ of cardiac tissue with significant reduction as compared with $\mathrm{CIH}$ group, however it was still significantly up-regulated as compared with normoxic group (table3, figure 4).

Table (4): Bcl-2 protein expression in heart cells in different studied groups.

\begin{tabular}{|l|l|l|l|l|}
\hline & $\begin{array}{l}\text { Normoxic } \\
\text { group }\end{array}$ & $\begin{array}{l}\text { CIH } \\
\text { group }\end{array}$ & $\begin{array}{l}\text { Normoxia+ } \\
\text { L.NAME }\end{array}$ & $\begin{array}{l}\text { CIH+L.NA } \\
\text { ME }\end{array}$ \\
\hline $\begin{array}{l}\text { Bcl-2 protein expression } \\
\text { (ng/mg) } \\
\text { Mean } \pm \text { S.D. }\end{array}$ & $1.9 \pm 0.2^{*}$ & $5.1 \pm 0.2^{\circ}$ & $1.8 \pm 0.2^{*}$ & $2.9 \pm 0.2^{* 0}$ \\
\hline
\end{tabular}

'Significant change compared with normoxic group.

* Significant change compared with CIH group.

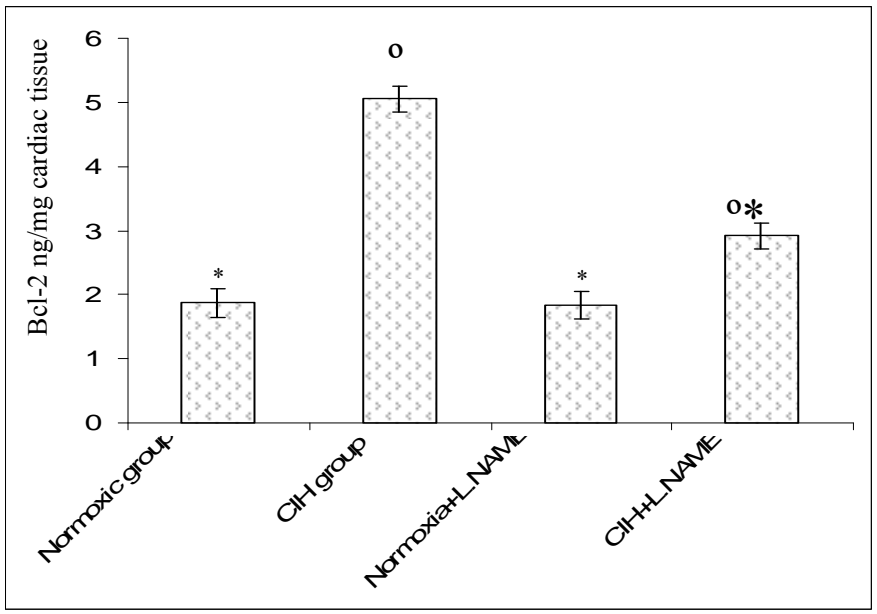

Fig. (4): Bcl-2 protein expression in heart cells in different studied groups ${ }^{\circ}$ Significant change compared with normoxic group ${ }^{*}$ Significant change compared with CIH group

\section{DISCUSSION}

The mammalian heart can be adapted to ischemia by repeatedly subjecting it to short-term reversible ischemia followed by short durations of reperfusion or by intermittent hypoxia. Such adaptation, generally known as preconditioning ( $\mathrm{PC}$ ), is cardio-protective as evidenced by its ability to reduce myocardial infarction, tissue injury, arrhythmias, and to improve post-ischemic ventricular functions. ${ }^{(6)}$

In the present study, adult rats exposed to 4 weeks of intermittent 
hypoxia had improved post ischemic left ventricular functions, as evidenced by significantly better recovery of LVDP, dp/dt, and HR, compared to normoxic group.

The majority of studies demonstrated that the hearts of adult chronically hypoxic animals exhibits better functional recovery following ischemia as compared to controls. ${ }^{(2)}$ Cai et al. (25) and Baker et al. ${ }^{(26)}$ demonstrated that adaptation to hypoxia increased the tolerance of adult rat hearts or of rabbit hearts on the $4^{\text {th }}$ day of postnatal life to ischemic reperfusion injury.

As cardiac protection against acute $I / R$ injury induced by chronic hypoxia is an important form of preconditioning and lasts markedly longer than any other form of preconditioning, (2) therefore its molecular mechanism is of particular interest for potential clinical application in the future. However, chronic hypoxia has been much less studied, and the understanding of its protective signaling is still limited. (27)

Preconditioning consisting of one or more episodes of ischemia/reperfusion or by episodes of hypoxia and normoxia causes the development of oxidative stress, Inhibition of oxygen free radical by antioxidants abolishes cardioprotection offered by chronic intermittent hypoxia. This is only possible if the reactive oxygen species potentiate the signal transduction cascade leading to preconditioning (PC). ${ }^{(28)}$

However, the amount of oxidative stress is not cumulative for each subsequent episode. The amount of oxidative stress generated lessens during each subsequent episode. During prolonged ischemia and reperfusion, the amount of oxidative stress is actually lower in the PC myocardium compared with non-PC hearts. ${ }^{(29)}$

Cellular necrosis inevitably follows extended periods of anoxia (i.e., oxygen absent) or severe hypoxia (i.e., oxygen supply decreased relative to metabolic demand). Hypoxic tolerance of various cell types differs, depending on the metabolic rate and intrinsic adaptive mechanisms of the tissue. Sublethal hypoxia, which may be transient and have no apparent consequences, can be followed by enhanced resistance to reoxygenation injury (conditioning). Post-hypoxic injury is due to a combination of changes in cellular energy charge, oxidant generating systems, and antioxidant defenses. ${ }^{(30)}$

Maulik et al. ${ }^{(28)}$ have demonstrated that acute myocardial ischemia and reperfusion resulted in apoptotic cell death, in addition to necrosis. Another study showed that PC provided cardioprotection by blocking apoptotic cell death. ${ }^{(6)}$

Oxidative stress developed in the ischemic reperfused myocardium was found to be instrumental for apoptotic cell death, because free radical scavengers were found to block apoptotic cell death simultaneously, providing myocardial protection ${ }^{(8)}$. So decreasing the amount of oxidative stress by exposure to chronic intermittent hypoxia, leads to reduction of apoptotic insult.

Other related studies suggested that prolonged reperfusion after ischemia caused down regulation of 
the antioxidant gene, Bcl-2, in concert with enhanced DNA fragmentation. The protective effect of chronic hypoxia may be related to enhanced Bcl-2 expression. ${ }^{(31)}$

Chronic hypoxia increases expression of hypoxia-inducible factor 1 (HIF-1) in the rat myocardium that mediates adaptive expression of other potentially protective proteins. (27) Several oxidative stress-inducible genes become activated during PC, of which Bcl-2 appears to be the most important gene that inhibits apoptosis. $^{(32)}$

The second finding in our study supports this suggestion. It was found that, rats exposed to chronic hypoxia had significantly higher rate of myocardial expression of antiapoptotic factor Bcl-2 as compared with normoxic rats.

Similar results were reported by Dougherty et al., (13) who suggested that exposure of isolated cardiac myocytes to chronic hypoxia is followed by activation of c-JUN- Nterminal Kinase (JNK) which promotes survival of myocytes after oxidative stress and they suggested that Bcl-2 family proteins are targets for phosphorylation by JNK.

Also, Maulik et al. ${ }^{(28)}$ suggested an inverse relation between cardiomyocytes apoptosis and the induction of the antioxidant gene, Bcl-2.

Bcl-2 may be regarded as an important cellular component that not only guards against apoptotic cell death but also impinges on multiple cellular events. Expression of Bcl-2 gene was found to be associated with inhibition of apoptosis mediated by multiple agents; $\mathrm{Ca} 2+$ ionophore, glucose withdrawal, membrane peroxidation, and free radical injury, suggesting that this gene is likely to play a role in reperfusion injury. ${ }^{(33)}$

The ratio of the antiapoptotic protein, $\mathrm{Bcl}-2$, and the proapoptotic protein, Bax, seems to be critical for cell survival. ${ }^{(\mathbf{3 4})}$ The activities of Bcl-2 proteins are regulated by phosphorylation. Phosphorylation may activate or inactivate the antiapoptotic function of Bcl-2 family proteins in a manner that is determined by the protein targets and the specific residue phosphorylated. ${ }^{(27)}$

One mechanism by which Bcl-2 prevents cell death during physiological and pathophysiological processes is through the inhibition of mitochondrial cytochrome $\mathrm{C}$ release. A reduction of $\mathrm{Bcl}-2$ leads to an increase of Bax homodimers resulting in translocation of $\mathrm{Bax}$ to mitochondrial membrane with subsequent mitochondrial dysfunction that leads to loss of membrane potential and release of cytochrome $\mathrm{C}$ into the cytosol. Cytochrome $\mathrm{C}$ then forms a complex with apoptosisactivating- factor, activating caspase 9, which triggers a proteolytic cascade leading to apoptotic cell death. ${ }^{(35)}$

Mitochondria from apoptotic cells produce increased quantities of

$\mathrm{O}_{2} \overline{2}$ because of a switch from normal four-electron reduction of $\mathrm{O}_{2}$ to oneelectron reduction after cytochrome $\mathrm{C}$ release. Over-expression of the antiapoptotic protein $\mathrm{Bcl}-2$ prevents increased $\mathrm{O}_{\overline{2}}^{-}$production associated with apoptosis. ${ }^{(36)}$

The third finding in the present study is that L-NAME treatment had no significant effect on the post 
ischemic/reperfusion ventricular function recovery or on myocardium expression of $\mathrm{Bcl}-2$ proteins in hearts of normoxic rats. On the other hand, L-NAME treatment significantly attenuated the improved functional recovery of ventricular function and the enhanced expression of $\mathrm{Bcl}-2$ proteins recorded in heart of rats exposed to chronic intermittent hypoxia.

Our results are in accordance with results of Baker et al., (26) and Fitzpatrick et al. ${ }^{(37)}$ who showed that acute inhibition of NOS activity by LNAME led to complete abolition of improved post ischemic recovery of contractility by chronic hypoxia in adults and neonatal rats.

However, Szarszoi et al. ${ }^{(38)}$ demonstrated that L-NAME had no effect on the improvement of post ischemic recovery of contractility in isolated, perfused hearts of hypoxic rats. On the other hand, Jones et al., ${ }^{(19)}$ reported that endogenously formed NO significantly contributes to ischemia reperfusion injury. This controversy may be due to different protocols, and animal species.

The results of the present work suggested that nitric oxide is an important mediator of adaptation to chronic hypoxia, as inhibition of NOS activity by L-NAME led to attenuation of improved postischemic recovery of the ventricular function provided by chronic hypoxia.

Previous studies showed that chronic hypoxia from birth increased NOS activity. They found that nitrite plus nitrate content (an index of NOS activity) was elevated in chronically hypoxic hearts. ${ }^{(39)}$
Other studies demonstrated that chronic hypoxia increased eNOS levels, gene expression, and activity in adult rats. (37) Chronic hypoxia increases HIF-1 in the rat myocardium that mediates expression of $\operatorname{NOS}^{(\mathbf{2 5})}$. Also, chronic hypoxia increased basal myocardial NO production by activation of constitutive NO synthase due to down regulation of caveolin$3 .^{(40)}$

Several lines of evidence suggested that during reperfusion after ischemia, there is excess production of NO through elevation of intracellular $\mathrm{Ca}^{2+}$, which stimulates $\mathrm{Ca}^{2+}$ dependent NOS in cardiac myocytes. Also reintroduction of molecular oxygen following ischemia favors generation of NO. ${ }^{(41 \& 42)}$

This increased NO is suggested to attenuate G1 cyclins and associated cyclin dependent kinases thought to mediate apoptosis in hypoxic cells. ${ }^{(43)}$

Generally the anti-apoptotic effects of $\mathrm{NO}$ can be mediated through a number of mechanisms such as the nitrosylation and inactivation of many of the caspases including caspase 3, caspase 1 and caspase $8 .^{(35)}$ Other mechanisms include activating $\mathrm{p} 53$, upregulating heat shock protein 70 (and consequently blocking recruitment of pro-caspase 9 to the Apaf-1 apoptosome). ${ }^{(44)}$

It has been proposed that endogenous NO plays a positive role in increased ischemic tolerance of chronically hypoxic rabbit hearts by a mechanism which involves activation of soluble guanylyl cyclase, accumulation of cyclic GMP, possible activation of cGMP-dependent protein kinase and phosphorylation of mitochondrial K-ATP channels. ${ }^{(37)}$ 
The molecular mechanisms underlying the NO/cGMP inhibition of apoptosis could involve the activation of cGMP-dependent protein kinase and the inhibition of caspase activation. However, the precise mechanism by which cGMP or PG kinase suppresses apoptotic signaling remains unknown.

Although endogenous inhibitors of caspase activation and activity have been described, none has been shown to be more prevalent than NO. An important feature of $\mathrm{NO}$ inhibition of caspase activity is that NO can rescue a cell from apoptosis even after the caspase cascade has been activated. Because NO easily diffuses within a cell, as well as from cell to cell, NO can efficiently guard against aberrant activation of caspases. The inhibition of caspase activation may then limit Bcl-2 degradation, (35) and thus explain the increase in Bcl-2 levels observed.

NO can oxidize intracellular reduced glutathione and thereby change the antioxidant levels within the cell, resulting in oxidative or nitrosative stress. This action stimulates the induction of heat shock proteins HSP32 (heme oxygenase) and HSP70, which protect cells from apoptotic cell death. ${ }^{(45)}$

Moreover, the accumulated data indicate that physiologically relevant levels of NO contribute to the balance between the antiapoptotic and proapoptotic forces within a cell by suppressing the apoptotic pathway at multiple levels and by several mechanisms Higher rates of NO production overwhelm cellular protective mechanisms and shift the balance toward apoptotic death in some cell types. ${ }^{(35)}$

Some studies suggest that NO has a proapoptotic effect as a result of the formation of peroxynitrite, inducing apoptotic DNA fragmentation and p53-dependent apoptosis. The formation of peroxynitrite is determined by the ratio of $\mathrm{NO}$ to superoxide, and the cellular susceptibility to peroxynitrite is dependent in large part on the levels of antioxidants (eg, thiols). ${ }^{(46)}$

However, beside its toxic effect, peroxinitrite is considered an important upstream event triggering mechanism of late preconditioning. ${ }^{(47)}$ Also it has been suggested that, the association of eNOS with heat shock protein 90, produced in stressful conditions, helps to produce $\mathrm{NO}$ and to limit superoxide generation. ${ }^{(44)}$

\section{Conclusion:}

It may be concluded that adaptation to chronic intermittent hypoxia increases cardiac tolerance to acute oxygen deprivation and reperfusion as shown by better recovery of cardiac function. This protective effect was associated with increased expression of the antiapoptotic protein Bcl-2 that limits the apoptotic cell death in the myocardium following the ischemic/ reperfusion insult.

It appears that increased synthesis of $\mathrm{NO}$ is one of the mechanisms by which chronic intermittent hypoxia offer this protection; since inhibition of NO production by L-NAME attenuated both the improved recovery of cardiac function and the expression of antiapoptotic protein $\mathrm{Bcl}-2$ induced by $\mathrm{CIH}$. 


\section{REFERENCES}

1. Yellon DM, Downey JM. Preconditioning the myocardium: from cellular physiology to clinical cardiology. Physiol Rev. 2003; 83:1113-1151.

2. Kolar,f, Ostadal,B, Molecular mechanisms of cardiac protection by adaptation to chronic hypoxia. Physiol Res. 2004; 53(suppl 1):s3-s13.

3. Maulik N, Das DK. Hunting for differentially expressed mRNA species in preconditioned myocardium. Ann N Y Acad Sci. 1996; 793:240-258.

4. Ostadalova I, Ostadal B, Jarkovska D and Kola F. Ischemic Preconditioning in Chronically Hypoxic Neonatal Rat Heart. Pediatric Research. 2002; 52:561-567.

5. Yeh ETH. Life and death in the cardiovascular system. Circulation. 1997; 95:782-786.

6. Maulik N, Kagan VE, Tyurin VA, Das DK. Redistribution of phosphatidylethanolamine and phosphatidylserine precedes reperfusion-induced apoptosis. Am J Physiol. 1998;274:H242$\mathrm{H} 248$

7. Kajstura J, Cheng W, Reiss $\mathbf{K}$, Clark WA, Sonnenblick EH, Krajewski S, Reed JC, Olivetti G, Anversa P. Apoptotic and necrotic myocyte cell deaths are independent contributing variables of infarct size in rats. Lab Invest. 1996; 74:86-107.

8. Webster KA, Discher D, Kaiser S, Hernandez OM, Saito B, Bishopric NH. Hypoxiaactivated apoptosis of cardiac myocytes requires reoxygenation oor a $\mathrm{pH}$ shift and is independent of p53. J Clin Invest.1999; 104:239-252

9. Namura S, Zhu J, Fink $K$, Endres M, Srinivasan A, Tomaselli KJ, Yuan J, Moskowitz MA Activation and cleavage of caspase-3 in apoptosis induced by experimental cerebral ischemia. $J$ Neurosci. 1998; 18(10):3659-68.

10. Jeroudi MO, Hartley CJ, Bolli R. Myocardial reperfusion injury: role of oxygen radicals and potential therapy with antioxidants. Am J Cardiol. 1994; 73:2B-7B.

11. Jung F, Weiland U, John RA, Ihling C, Dimmeler S. Chronic hypoxia induces apoptosis in cardiac myocytes: a possible role for Bcl-2 like proteins. Biochemical and Biophysical Research Communications. 2001; 419-425.

12. Kang PM, Haunstetter A, Aoki H, Usheva A, Izumo S. Morphological and molecular characterization of adult cardiomyocyte apoptosis during hypoxia and reoxygenation. Circ Res. 2000;87(2):118-25.

13. Dougherty $C$, Kubasiak LA, Prentice $\mathrm{H}$, Andreka $\mathrm{P}$, Bishopric NH, Keith A. Activation of c-Jun N-terminal kinase promotes survival of cardiac myocytes after oxidative stress. Biochem J.2002; 362: 561571.

14. Green DR, Reed JC. Mitochondria and apoptosis. Science. 1998; 281:1309-1312. 
15. Adams JM, Cory S. The Bcl-2 protein family: arbiters of cell survival. Science. 1998; 281:1322-1326.

16. Gonzalez-Garcia $M$, PerezBallestero R, Ding L, Duan L, Boise LH, Thompson CB, Nunez G. bcl-XL is the major bcl-x mRNA form expressed during murine development and its product localizes to mitochondria. Development. 1994; 120:3033-3042.

17. Misao J, Hayakawa Y, Ohno M, Kato S, Fujiwara T, Fujiwara H. Expression of bcl-2 protein, an inhibitor of apoptosis, and Bax, an accelerator of apoptosis, in ventricular myocytes of human hearts with myocardial infarction. Circulation. 1996; 94:1506-1512.

18. Brocheriou V, Hagege AA, Oubenaissa A, Lambert $\mathbf{M}$, Mallet VO, Duriez M, Wassef M, Kahn A, Menasche P, Gilgenkrantz H. Cardiac functional improvement by a human Bcl-2 transgene in a mouse model of ischemia/reperfusion injury. $J$ Gene Med. 2000;2(5):326-33.

19. Jones P, James Greer J M, Kakkar A K, Ware D P, Turnage RH, Hicks M, Haperen R, Crom R, Kawashima S, Yokoyama M, David J. Endothelial nitric oxide synthase overexpression attenuates myocardial reperfusion injury. Am J Physiol Heart Circ Physiol 2003; 286: H276-H282.

20. Ferdinandy $\mathbf{P}$, Schulz R. Nitric oxide, sureroxide, and peroxinitrite in myocardial ischemia-reperfusion injury and preconditioning. Br J Pharmacol. 2003; 138:532-543.

21. Shirai M, Pearson J, Shimouchi A, Nagaya, H Tsuchimochi, Ninomiya I and Mori H Changes in functional and histological distributions of nitric oxide synthase caused by chronic hypoxia in rat small pulmonary arteries British Journal of Pharmacology (2003) 139, 899-910.

22. Costa M A, Balaszczuk A M, Dominguez A, Catanzaro $\mathbf{O}$, Arranz C. Effects of L-NAME and L-Arg on arterial blood pressure in normotensive and hypertensive streptozotocin diabetic rats. Acta Physiol Pharmacol Ther Latinoam. 1998; 48(2):59-63.

23. Bishopric H, Discher J, Kaiser S, Hernandez O, Sato B, Zang J, Webster A. Hypoxia-activated apoptosis of cardiac myocytes requires reoxygenation or a $\mathrm{pH}$ shift and is independent of p53. J Clin Invest, August 1999, Volume 104, Number 3, 239-252.

24. Wallenstein S, Zucker CL, Fleiss JL. Some statistical methods useful in Circulation Research. Circ Res. 1980;47:1-9.

25. Cai Z, Manalo J, Wei G, RodriguezR,; -Talbot KF, Lu H, Zweier L., Semenza GL Hearts From Rodents Exposed to Intermittent Hypoxia or Erythropoietin Are Protected Against Ischemia-Reperfusion Injury. Circulation. 2003; 108:79-90.

26. Baker EJ, Boerboom LE, Olinger GN, Baker JE. 
Tolerance of the developing heart to ischemic impact of hypoxemia from birth. Am J Physiol. 1995; 268: H1165-H1173.

27. Forkel J, Chein X, Wandinger S, Keser F, Duschin A, Schwanke U, Frede $S$, Massoudy P, Schulz R, Jacob H, Heusch G. Responses of chronically hypoxic rat hearts to ischemic KATP channel blockade does not increased RV tolerance to ischemia. Am J Physiol. 2004; 286:545-551.

28. Maulik N, Richard M. Engelman, John A. Rousou, Joseph E. Flack, III, MD; David Deaton, MD; Dipak K. Das, PhD Ischemic Preconditioning Reduces Apoptosis By Upregulating AntiDeath Gene Bcl-2 Circulation. 1999;100:II-369)

29. Das DK, Maulik N, Moraru II. Gene expression in acute myocardial stress. Induction by hypoxia, ischemia/reperfusion, hyperthermia and oxidative stress. J Mol Cell Cardiol. 1995; 27:181-193.

30. Li C, Jackson M. Reactive species mechanisms of cellular hypoxia-reoxygenation injury. $J$ Physiol Cell Physiol, 2002; 282: C227-C241.

31. Dong JW, Zhu HF, Zhu WZ, Dong HL, Ma TM, Zhou ZN. Intermittent hypoxia attenuates ischemia/reperfusion induced apoptosis in cardiac myocytes via regulating $\mathrm{Bcl}-2 /$ bax expression. Cell Res. 2003; 13:385-391.

32. Semenza G. Surviving ischemia: adaptive responses mediated by hypoxia-inducible factor 1 . J Clin Invest. 2000; 106(7): 809-812.

33. Zhong LT, Sarafian T, Kane DJ, Charles AC, Mah SP, Edwards RH, Bredesen DE. Bcl-2 inhibits death of central neural cells induced by multiple agents. Proc Natl Acad Sci U S A. 1993; 90:4533-4537.

34. Gross A, Jockel J, Wie MC, Korsmeyer T. Enforced dimerization of Bax results in its translocation, mitochondrial dysfunction, and apoptosis. EMBO J. 1998; 17: 3878-3885.

35. Kim YM, Bombeck CA, Billiar Pignatti RC, Stefanelli C. Nitric Oxide as a Bifunctional Regulator of Apoptosis. Circulation Research. 1999;84:253-256m

36. Chuanyu Li and Robert $M$. Jackson. Reactive species mechanisms of cellular hypoxiareoxygenation injury. $A m \mathrm{~J}$ Physiol Cell Physiol , 2002;.282: C227-C241.

37. Fitzpatrick M, Shi Y,. Hutchins C, Su J, Gross G J, Ostadal B, Tweddell $\mathbf{J}$ S, J Baker $\mathbf{E}$. Cardioprotection in chronically hypoxic rabbits persists on exposure to normoxia: role of NOS and $\mathrm{K}_{\mathrm{ATP}}$ channels. Am J Physiol Heart Circ Physiol. 2005; 288: H62-H68.

38. Szarszoi O, Asemu G, Ostadal B, Kolar F. Cardioprotection by chronic hypoxia: role of nitric oxide. Physiol Res. 2002; 51:69p$77 \mathrm{p}$.

39. Ashwal S, Tone B, Tian H, Cole DJ, and Pearce WJ. Core and penumbral nitric oxide synthase activity during cerebral ischemia 
and reperfusion. Stroke.1998; 29: 1037-1046,

40. Shi Y, Pritchard KA, Holman P, Rafief $P$, Griffith $O W$, Kalyanaraman B, Baker JE. Chronic hypoxia increases nitric oxide synthase and decreases caveolin-3. Free Radic Biol Med. 2000; 29:695-703.

41. Flogel U, Decking UK, Godecke A, Schrader J. contribution ofNO to ischemia-reperfusion injury in the saline-perfused heart: a study in endothelial NO synthase knockout mice. $\mathrm{J} \mathrm{Mol}$ Cell Cardiol. 1999; 31:827-836.

42. Kirshenbaum LA, de Moissar D. The Bcl-2 gene product prevents programmed cell death of ventricular myocytes. Circulation. 1997; 96:1580-1585.

43. Christopher A., Timothy R.C. Ischemia/reperfusion-induced apoptosis: connecting nitric oxide and cell cycle regulators. Cardiovasc Res. 2003; 59: 268270.

44. Shi Y, Baker JE, Zhang C, Tweddell J, Su J, Pritchard
KA. Chronic hypoxia increases endothelial nitric oxide synthase generation of nitric oxide by increasing heat shock protein 90 association and serin phosphorylation. Circ Res. 2002; 91:300-306.

45. Kim YM, de Vera ME, Watkins SC, Billiar TR. Nitric oxide protects cultured rat hepatocytes from tumor necrosis factor-alphainduced apoptosis by inducing heat shock protein 70 expression. J Biol Chem. 1997;272:14021411

46. Dash PR, Cartwright JE, Baker PN, Johnstone AP, Whitley GS. Nitric oxide protects human extravillous trophoblast cells from apoptosis by a cyclic GMPdependent mechanism and independently of caspase 3 nitrosylation. Exp Cell Res. 2003; 287(2):314-24

47. Boli R. The late phase of preconditioning. Circ Res. 2000; 87:972-983. 


\section{الملخص العربي \\ سماح العطار المعاري \\ قسم القسيولوجى- كلية الطب - جامعة القاهرة}

أثتبت الأبحاث أن نقص الأكسجة المتقطع بزوّد القلب بحماية ضد الاصابات

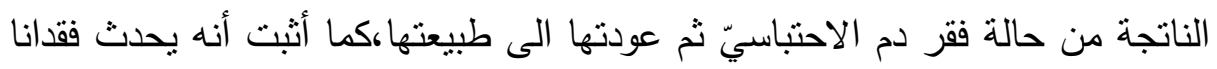
للخلايا عن طريق الموت المبرمج في حالات الاصابات الناتجة من نقص الدورة

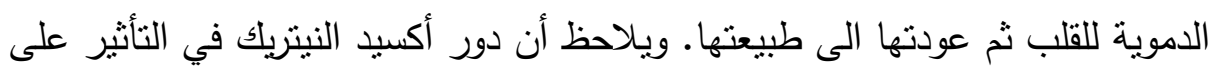
الموت المبرمج للخلايا في حالات نقص كمية الأكسجين المتقطع المزمنة غير واضح. الهدف من هذه الدراسة هو أن تتحرّى امكانية وجود دور لمثبطات الانزيم المصنع لأكسيد النيتريك في التأثير على الموت المبرمج لخلايا القلوب المعرضة لنقص الدورة الدموية للقلب ثم عودتها الى طبيعتها في الفئران التي سبق تعريضها لنقص كمية الأكسجين المتقطع المزمنة. استخدمت ذكور فئران بالغة في هذه الدراسة و تم تقسيم الفئران الى أربع

مجموعات:

المجموعة الأولى: شملت عشرة فئران تعرضت للنسبة الطبيعية من

الأكسيجين ثم تعرضت الى حالة فقر دم الاحتباسيّ ثم عودتها الى طبيعتها.

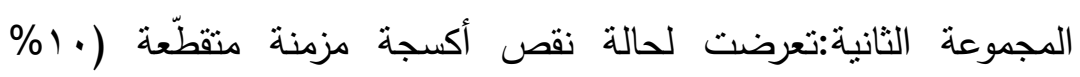

اكسجين و • 9\%نبتروجين لمدة ^ ساعات يوميّة، بعد ذلك إلى هواء عادى بقية اليوم، ه أيام / أسبوع لمدة ع أسابيع..

المجموعة الثالثة: تعرضت للنسبة الطبيعية من الأكسيجين مع اعطائها لن

$$
\text { ام ي (• مغ اكغ وزن) عن طريق المعدة. }
$$

المجموعة الرابعة:تعرضت الى حالة نقص أكسجة مزمنة متقطّعة مع اعطائها

$$
\text { لـن ام ي (• مغ/كغ وزن) عن طريق المعدة. }
$$


عرضت القلوب المعزولة إلى • ب دقائق من حالة فقر دم احتباسيّ شاملة

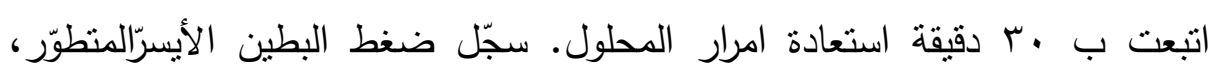
قابليّةالانقباض، و عد النبضات باستمرار .و تم قياس انتاج ال [ب.سي.ل-r] في عضلة القلب.

كانت النتيجة أن تحسنت المؤشرات الوظيفيّة في المجموعة التي تعرضت

لحالة نقص أكسجة مزمنة متقطّعة مع زيادة هامّة إحصائيا في انتاج [ب.سي.ل-ب]

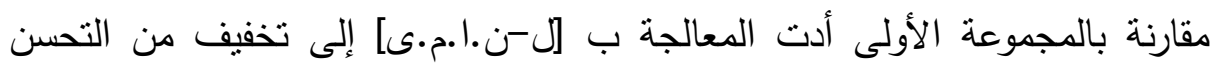
في وظائف القلب بعد اعادة امرار المحلول الملحوظ في المجموعةالتي تعرضت لنقص لهص

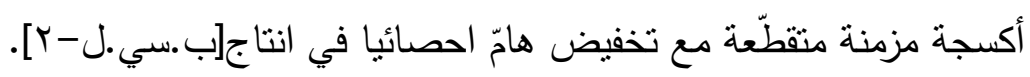
الاستنتاج: - الاحنه

يزيد تكييف القلب لحالة نقص الأكسجة المثقطّعة المزمنة من تحمل القلب إلى حالة فقر دم احتباسيّ ثم اعادة امرار المحلول. صحبت هذا التأثير الواقي زيادة إنتاج [ب.سي.ل-r]، واستطاع أنّ يحدّ من فقدان الخلايا عن طريق الموت المبرمج وأن استخدام ال[لن.ا.م.ى] أضعف التحسن الملحوظ في وظائف القلب والزيادة

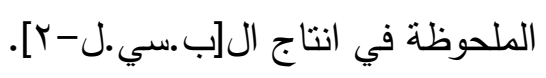

